\title{
ANALISIS PENERAPAN LATIHAN SKIPPING UNTUK MENINGKATKAN KECEPATAN TENDANGAN ATAS PADA ATLET BELADIRI KARATE
}

\author{
${ }^{1}$ Ahmad Yanuar Syauki, ${ }^{2}$ Bambang Yunanto, dan ${ }^{3}$ Siti Maesaroh \\ ${ }^{1}$ Sekolah Tinggi Keguruan dan Ilmu Pendidikan Banten \\ ${ }^{2}$ Sekolah Tinggi Keguruan dan Ilmu Pendidikan Banten \\ ${ }^{3}$ Mahasiswa Pendidikan Jasmani, Kesehatan dan Rekreasi \\ Penulis Korespondensi: aysyauki@yahoo.com ${ }^{1}$, bambangyunanto01@gmail.com², \\ mayysaroh.8@gmail.com ${ }^{3}$ \\ Artikel : Kecepatan Tendangan Atas Pada Atlet Beladiri Karate \\ Penerima: Juli, 2021 Diterima: Agustus, 2021 Dipublikasikan: September, 2021
}

\begin{abstract}
This study aims to analyze the application of skipping exercises to increase the speed of upper kicks in karate martial arts athletes, the method used in this study is a literature study. Literature study can also be called a literature study whose sources are taken from relevant previous research both in terms of variable $x$, variable $y$ and variables $x$ and $y$. Based on relevant sources analyzed concluded that the application of skipping exercises can increase kick speed, this is seen from the influence analyzed from relevant sources. Previous research that is relevant is evidenced by the validity test, it can be concluded that there is an increase in the speed of the upper kick in athletes who apply skipping exercises in their training program. it can also be concluded that skipping exercise significantly increases the success of kicking speed.
\end{abstract}

Keywords : Skipping Exercise, Top Kick Speed, karate

\begin{abstract}
ABSTRAK
Penelitian ini bertujuan untuk menganalisis penerapan latihan skipping untuk meningkatkan kecepatan tendangan atas pada atlet beladiri karate, metode yang digunakan pada penelitian ini adalah studi literatur. Studi literatur bisa disebut juga studi pustaka yang sumber-sumbernya diambil dari penelitian terdahulu yang relevan baik secara variabel $\mathrm{x}$, variabel y maupun variabel $\mathrm{x}$ dan $\mathrm{y}$. Berdasarkan sumber-sumber relevan yang dianalisis menyimpulkan bahwa penerapan latihan skipping mampu
\end{abstract}


meningkatkan kecepatan tendangan, hal ini dilihat dari pengaruh yang dianaisis dari sumber-sumber yang relevan. Penelitian terdahulu yang relevan dibuktikan dengan uji keabsahan dapat disimpulkan bahwa terjadinya peningkatan kecepatan tendangan atas pada atlet yang menerapkan latihan skipping dalam program latihannya. dapat disimpulkan juga bahwa latihan skipping secara signifikan terhadap keberhasilan mampu meningkatkan kecepatan tendangan.

Kata kunci: Latihan Skipping, Kecepatan Tendangan Atas, Beladiri Karate

\section{PENDAHULUAN}

Olahraga karate merupakan salah satu cabang olahraga beladiri menggunakan anggota tubuh tanpa senjata, yang terlatih baik dan alami dengan adanya potensi diri yang bisa menjadi senjata mematikan. Cabang olahraga tersebut pada dasarnya mempunyai agresivitas yang tinggi. Selain mengajarkan kuat fisik dan pandai mental. Sikap mental tersebut antara lain pengendalian diri, berani disiplin, dan cenderung memiliki sifat agresif yang tinggi.

Bagi Sebagian orang, nama beladiri ini mungkin sudah tidak asing karena cukup dikenal keberadaannya. Karate berasal dari Jepang, dibawa ke Indonesia oleh mahasiswa Indonesia yang saat itu tengah kuliah di Jepang. Mereka adalah Baud AD Adikusumo, Karianto Djojonegoro, Mochtar Ruskan, dan Ottoman Noh. Mereka mempelajari karate ketika berada di Jepang (Syahril, 2020). bertarung, beladiri juga mengajarkan sikap

Kegiatan olahraga ini bisa dijadikan untuk menjaga stamina tubuh dan juga bisa dilakukan untuk meraih prestasi. Saat ini banyak pemuda-pemudi Indonesia yang menjadikan olahraga sebagai cita-cita untuk meraih prestasi demi masa depan mereka, misalnya saja olahraga beladiri karate. Pada zaman sekarang ini, di Indonesia tidak sedikit pemuda yang suka olahraga beladiri karate.

Pembinaan olahraga prestasi harus mengembangkan olahragawan secara terencana, berjenjang, dan berkelanjutan melalui kompetensi dengan dukungan ilmu pengetahuan dan teknik keolahragaan. Dari sekian banyak cabang olahraga yang dikembangkan saat ini, salah satunya yang mendapat perhatian dan pembinaan adalah olahraga atlet karate.

Salah satu Dojo di kabupaten serang yang membuka cabang olanhraga beladiri karate ini adalah Dojo Kaswa. Dilihat dari prestasinya Atlet Karate Dojo Kaswa ini tergolong sering mendapatkan prestasi. Namun, menurut Kasli Wardnius, (2021) selaku pelatih, dari sebagian atlet yang sering mendapatkan juara di setiap 
Ahmad Yanuar Syauki ${ }^{1}$, Bambang Yunanto ${ }^{2}$, dan Siti Maesaroh ${ }^{3}$. Analisis Penerapan Latihan Skipping Untuk Meningkatkan Kecepatan Tendangan Atas Pada Atlet Beladiri Karate

pertandingan Provinsi ataupun Nasional, masih terdapat kohai atau atlet yang belum bisa menguasai teknik kecepatan tendangan atas dengan cepat, sehinngga hal ini dapat mengakibatkan rentangnya kekalahan pada pertandingan.

Tendangan atas merupakan salah satu teknik dalam karate. Tendang atas juga bisa dianggap tendangan yang dominan digunakan dalam karate, karena tendangan atas mampu mendapatkan point yang lebih banyak dari tendangan dalam karate lainnya yang sering digunakan di pertandingan kumite. Tendangan atas untuk mengenai sasaran seperti muka, leher, punggung.

Skipping merupakan salah satu olahraga sederhana yang dapat mempertahankan kesegaran jasmani. Skipping adalah aktivitas fisik berbiaya rendah, dampaknya terhadap kebugaran fisik sedang dipelajari oleh berbagai peneliti. Skipping adalah gerakan melompat yang menggunakan otot-otot di lengan dan kaki, yang juga dapat juga meningkatkan fungsi kardiovaskular dan metabolisme (Pramudani, Kumaidah \& Hardia, 2018).

\section{LANDASAN TEORI}

\section{Pegertian Latihan Skipping \\ a. Pengertian Latihan}

Latihan merupakan susatu hal pembiasaan yang berulang-ulang. latihan disebut juga dengan suatu kegiatan yang dilakukan dengan beban sama setiap harinya atau semakin bertambah setiap harinya tergantung dari program latihan yang kita buat.

Latihan merupakan suatu proses yang sistematis dari berlatih secara berulang-ulang, maka kian hari akan bertambah jumlah beban latihan proses". Sementara Harsono megungkapkan bahwa "latihan proses yang sistematis dari berlatih atau bekerja, yang dilakukan berulang-ulang". Bompa "Latihan adalah suatu aktivitas olahraga yang dilakukan secara sistematis dalam waktu yang lama ditingkatkan secara progresif dan individual yang mengarah kepada cirri-ciri fungsi fisiologis dan psikologis untuk mencapai sasaran yang ditentukan" (Purba, Bangun \& Siahaan, 2019 : 45).

\section{b. Pengertian Skipping}

Skipping yaitu olahraga sederhana yang bisa menggunakan alat dengan seutai tali yang mudah didapatkan. Skipping merupakan olahraga murah meriah yang kalangan apa saja bisa melakukannya. Teknik yang dimiliki olahraga ini pun termasuk teknik yang mudah dikuasai banyak orang.

Menurut Magfirah, (2016 : 26) Skipping adalah satu jensi olahraga yang 
menggunakan alat bantu berupa tali dan diputar dengan menggunakan pergelangan tangan sebagai tumpuan atau poros. Olahraga skipping merupakan salah satu olahraga yang efektif membakar lemak, disamping lari atau jogging. Pun juga skipping bisa dilakukan dalam tempat yang tidak terlau luas, sehingga efektif diterapkan di sekitar rumah. Selain membakar lemak tubuh, skipping juga bermanfaat melatih keseimbangan otot pergelangan tangan dan pernapasan. Olahraga skipping dilakukan dengan kombinasi gerakan melompat seiring dengan rintangan berupa tali yang bergerak pada kedua poros pergelangan tangan.

Permainan lompat tali atau skipping yaitu gabungan antara gerak lompat menggunakan tali sebagai alat bantunya, untuk memindahkan jarak vertikal dan jarak horizintal, tali yang digunakan terbuat dari sutra, serat manila, nilon atau bahan karet, dan panjang tali 10-12 kaki. Pengertian lompat tali atau skipping adalah gerakan lompat ringan dengan kedua kaki lurus diudara, kedua lengan horizontal ke samping dan sebagian besar putaran tali dengan gerakan pergelangan tangan, tali tidak menyentuh lantai, tetapi harus melalui sedikit di atasnya dan semua gerakan lompat dimulai dari belakang (Afrizal, 2018).

\section{c. Tujuan skipping}

Latihan lompat tali skipping adalah memaksimalkan ukuran jarak capai atau tinggi loncatan dan untuk menyelaraskan, mengkoordinasikan loncatan dengan ayunan supaya tali dapat melewati kaki dan kepala dan mampu mengembangkan kekuatan kaki dengan banyaknya loncatan yang dilakukan.

\section{d. Teknik Dan Variasi Dalam Skipping}

Variasi dalam lompat tali/skipping ada enam cara menurut Chrissie Gallagher yaitu: (1) angkat satu lutut sambil melompat, (2) melompat maju mundur, setelah itu ke samping, (3) lompati tali dengan kedua kaki secara 27 bersamaan, (4) lompati tali dengan lompatan tali disilangkan, (5) lakukan lompatan yang tinggi di atas tali, dan (6) melakukan lompatan bintang (star jump) di antara waktu ketika tali berada di bawah. Menurut Muhyi Faruq dalam melakukan lompat tali ada beberapa cara antara lain adalah sebagai berikut: (1) melompati tali ditempat dengan menggunakan kedua kaki, (2) melompati tali dengan salah satu kaki bergantian, (3) melompati tali dengan satu kaki bergantian sambil berjalan. Dalam penelitian ini latihan skipping dilakukan dengan cara meloncat satu kaki bergantian kanan dan kiri, masing-masing kaki 10 repetisi dan meningkat 4 repetisi setiap 3 kali petemuan, setiap pertemuan 4 
Ahmad Yanuar Syauki ${ }^{1}$, Bambang Yunanto ${ }^{2}$, dan Siti Maesaroh ${ }^{3}$. Analisis Penerapan Latihan Skipping Untuk Meningkatkan Kecepatan Tendangan Atas Pada Atlet Beladiri Karate

set, dilakukan dengan irama secepat mungkin (eksplosif), recovery 30 detik antar set, pemberian perlakuan dilakukan 3x seminggu dengan lama pemberian 16 kali tatap muka (Warisyanti).

\section{e. Kelebihan Latihan Skipping}

Laitihan skipping juga mempunyai kelebihan atau manfaat bagi tubuh kita, selain bertujuan untuk meningkatkan tinggi loncatan yaitu : (1) Merupakan olahraga yang sederhana, (2) Alat yang digunakan mudah didapat, (3) Termasuk olahraga yang murah meriah, (4) Cara atau teknik olahraga mudah dikuasai banyak orang, (5) Meningkatkan Kapabilitas, (6) Menurunkan Berat Badan, (7) Mengencangkan Otot,

Mengoptimalkan Energi Dalam Tubuh, (9) Membentuk tubuh, (10) Menambah Tinggi Badan, (11) Meningkatkan Fertilitas, (12) Mencegah osteoporosis, (13) Meningkatkan Stamina dan Keseimbangan, (14) Meningkatkan Kinerja Otak.

\section{f. Kekurangan Skipping}

Selain memiliki kelebihan skipping juga memiliki kekurangan seperti akan mengalami kelelahan otot bagi pengguna skipping yang menggunakan programnya tanpa ukuran sewajarnya.

\section{g. Instrumen Penilaian Skipping}

Adapun instrumen penilaian dalam penelitian loncat tali Skipping.

\section{Loncat Tali Skipping}

Tujuan : Mengukur kelincahan, daya tahan jantung, peredaran darah dan pernafasan.

Perlengkapan : Tali, stopwatch, alat penghitung, formular, dan alat tulis.

Petugas : (1) Pengambil waktu 1 orang, pengawas 1 orang, pencatat 1 orang, pencatat 1 orang.

Pelaksanaan : Pada aba-aba "Siap", testi berdiri tegak, kedua tangan memegang tali, (2) tali harus berada di belakang testi, (3) pada aba-aba "YA", testi melakukan loncatan dengan cepat. Bersamaan dengan itu stopwatch dijalankan, (4) loncatan dilakukan sebanyak mungkin selama 60 detik tanpa istirahat, (5) ketika aba-aba "STOP", pada detik ke-60 stopwatch dihentikan, (6) tes dilakukan 3 kali, (3x60 detik) dengan istirahat 30 detik.

Penilaian : (1) hasil 1 trial adalah jumlah loncatan yang dapat dilakukan selama 60 detik, (2) catat ketiga hasil tersebut dan jumlah loncatan terbanyak merupakan hasil tes.

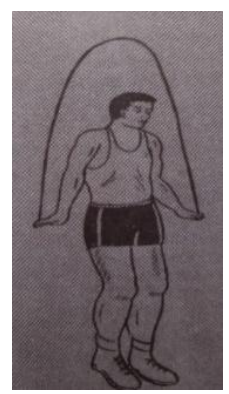

Gambar 3.1 : L0mpat Tali (Skipping) Sumber : Fenanlampir \& Faruq, 2015 


\section{Kecepatan Tendangan}

\section{a. Pengertian Kecepatan}

Kecepatan adalah kemampuan bergerak dengan kemungkinan kecepatan tercepat. Ditinjau dari sistem gerak, kecepatan adalah kemampuan dasar mobilitas sistem saraf pusat dan perangkat otot untuk menampilkan gerakan-gerakkan pada kecepatan tertentu. Menurut Bomba "Dari sudut pandang mekanika, kecepatan sebagai rasio antara jarak dan waktu. Kecepatan merupakan gabungan dari tiga elemen, yakni waktu reaksi, frekuensi gerak per unit waktu, kecepatan menempuh suatu jarak (Fenanlampir \& Faruq, 2015).

Kecepatan Tendangan merupakan kualitas kondisional yang seorang sesingkat-singkatnya bila dirangsang. Seperti yang dikatakan oleh Sukadiyanto, kemampuan menjawab rangsang dengan bentuk gerak atau serangkaian gerak dalam waktu secepat mungkin. Kecepatan juga diartikan sebagai kemampuan untuk berjalan, berlari atau bergerak dengan cepat (Bagia, 2016).

\section{b. Teknik Tendangan Atas}

Teknik serangan tendangan adalah suatu teknik kaki yang dilakukan secara terarah pada lawan atau sasaran, sesuai dengan teknik dasar. olahragawan dapat melakukan gerakan

Teknik - teknik dasar tendangan dalam olahraga karate ada banyak, seperti: maegeri, mawashigeri, keikomegeri, keage, tubigeri, assimawassigeri, dan sebagainya.

Teknik tendangan atas, karateka berdiri dengan mempersiapkan kuda-kuda, mengangkat kaki setinggi pinggang dan mengarahkan kaki ke arah sasaran (Fandayani \& Sagitarius, 2019 : 23).

\section{c. Jenis-Jenis Tendangan Karate}

Dalam tendangan karate terdapat beberapa jenis tendangan sebagai berikut:

(1) Mae Geri adalah tendangan yang paling dasar dari segala macam tendangan dalam karate. dan digunakan lebih dari semua tehnik tendangan jadi penting untuk para pemula tahu bagaimana melakukan nya untuk memulai teknik ini kita akan mengasumsikan bahwa kita berdiri di zenkutsu dach (sikap depan) saat melakukan serangan

(2) Yoko Geri Keage adalah Tendangan yang dilakukan dari sisi tubuh dengan kekuatan kaget, Oleh karena itu, dalam rangka untuk membuat yoko geri keage yang efektif, sangat penting untuk menggunakan pinggul. caranya adalah sangat mudah, namun, karena banyak orang telah lama digunakan untuk melakukan tendangan tanpa menggunakan pinggul, mereka sering menemukan perubahan yang sulit. 
Ahmad Yanuar Syauki ${ }^{1}$, Bambang Yunanto ${ }^{2}$, dan Siti Maesaroh ${ }^{3}$. Analisis Penerapan Latihan Skipping Untuk Meningkatkan Kecepatan Tendangan Atas Pada Atlet Beladiri Karate

Prinsip menggunakan pinggul di yoko geri keage sangat mirip dengan gerakan pinggul di Mawashi geri.

(3) Yoko Geri Kekomi yaitu Tendangan menyamping dengan dorongan berat tubuh, perbedaan dengan Yoko Geri Keage adalah efek lecutan tendangan (Keage) sementara Kekomi adalah efek dorongan kaki. Pertama, harus ditentukan bahwa yoko-geri-kekomi adalah tendangan mendorong secara linear. Ini menggabungkan kekuatan pinggul dengan gerakan menyodorkan kaki. Hal ini dapat ditujukkan pada tingkat manapun (jodan: Hidung, rahang, leher; chudan: rusuk, solar plexus, ginjal, perut dan gedan: paha, lutut dan tulang kering), meskipun penggunaannya di tingkat jodan berisiko. Meskipun yoko-geri-kekomi dapat dilakukan dari berbagai start posisi kuda kuda (heisoku-Dachi, hachinoji-Dachi, heiko-Dachi, dll), sikap yang paling umum digunakan adalah kibadachi.

(4) Mawashi-geri Dapat diterjemahkan sebagai "tendangan berputar", meskipun juga kadang-kadang disebut sebagai tendangan bangsal lokomotif. Mawashi-geri dapat dieksekusi dari berbagai sikap, dan ada beberapa metode pelaksanaan yang tepat. Porsi pelaksanaannya yang selalu konsisten adalah bahwa tendangan yang dieksekusi ke dalam dan pada sudut yang mana saja yang sejajar dengan lantai ke arah 45 derajat ke atas. Secara umum, itu adalah tendangan lateral yang menyerang dengan kaki.

(5) Ushiro-geri adalah pertahanan ke belakang, tetapi lebih sering sebagai teknik serangan. Ada beberapa tehnik dalam tendangan Ushiro antara lain: Ushiro-geri Kekomi (tendangan lurus mundur), Ushiro Mawashi-geri (tendangan mundur setengah lingkaran).

\section{d. Faktor Yang Mempengaruhi Tendangan Atas}

Faktor yang mempengaruhi tendangan atas antara lain :

1) Kecepatan Tendangan merupakan kualitas kondisional yang seorang olahragawan dapat melakukan gerakan sesingkat-singkatnya bila dirangsang. Seperti yang dikatakan oleh Sukadiyanto, kemampuan menjawab rangsang dengan bentuk gerak atau serangkaian gerak dalam waktu secepat mungkin. Kecepatan juga diartikan sebagai kemampuan untuk berjalan, berlari atau bergerak dengan cepat. Sedangkan menurut Sukadiyanto yang dimaksud dengan kecepatan adalah kemampuan bergerak dari satu titik ke titik lain setelah mendapat rangsang, 
2) Panjang tungkai adalah jarak vertikal antara telapak kaki sampai dengan pangkal paha yang diukur dengan cara berdiri tegak. Panjang tungkai sebagai bagian dari postur tubuh memiliki hubungan yang sangat erat dalam kaitannya sebagai pengungkit,

3) Berat badan merupakan hasil peningkatan atau penurunan semua jaringan yang ada pada tubuh. Pengukuran berat badan digunakan untuk menilai hasil peningkatan atau penurunan semua jaringan yang ada pada tubuh, misalnya tulang, otot, organ tubuh, dan cairan tubuh sehingga dapat diketahui status gizi dan tumbuh kembang anak, berat badan juga dapat digunakan sebagai dasar perhitungan dosis dan makanan yang diperlukan dalam tindakan pengobatan.

Penilaian berat badan berdasarkan usia menurut WHO dengan standar NCHS (National Center for Health Statistics) yaitu menggunakan persentil sebagai berikut: persentil kurang atau sama dengan tiga termasuk kategori malnutrisi. Penilaian berat badan berdasarkan tinggi badan menurut WHO yaitu menggunakan persentase dari median sebagai berikut: antara $89 \pm 100 \%$ dikatakan malnutrisi sedang dan kurang dari $80 \%$ dikatakan malnutrisi akut (wasting).
Penilaian berat badan berdasarkan tinggi menurut standar baku NCHS yaitu menggunakan persentil sebagai berikut persentil $75 \pm 25 \%$ dikatakan normal, pesentil $10 \%$ dikatakan malnutrisi sedang, dan kurang dari persentil dikatakan malnutrisi berat (Bagia, 2016).

\section{e. Instrumen Penilaian Kecepatan Tendangan}

Adapun instrumen penilaian dalam penelitian kecepatan tendangan atas yaitu.

\section{Kecepatan Tendangan}

Tujuan : mengukur kemampuan kecepatan tendangan mawashi geri atlet karate.

Peralatan : target (handbox/patching pad), meteran, stopwatch.

Petugas : pengambil waktu, pengawas, pencatat hasil.

Pelaksanaan : (1) ketika aba-aba "BERSIAP" atlet berdiri didepan target dengan kaki tumpu berada dibelakang garis sejauh $50 \mathrm{~cm}$ (puteri) $60 \mathrm{~cm}$ (putera) untuk bersiap menendang, (2) pada saat aba-aba "YA", stopwatch diaktifkan dan atlet melakukan tendangan yang benar dengan kaki kanan dan kembali ke posisi awal dengan menyentuh lantai yang berada di belakang garis, (3) kemudian melanjutkan tendangan kaki kanan secepat-cepatnya dan tendangan dilakukan sebanyak 3 tendangan, (4) pada saat 
Ahmad Yanuar Syauki ${ }^{1}$, Bambang Yunanto ${ }^{2}$, dan Siti Maesaroh ${ }^{3}$. Analisis Penerapan Latihan Skipping Untuk Meningkatkan Kecepatan Tendangan Atas Pada Atlet Beladiri Karate

tendangan ke 3 ketika kaki mengenai target lalu mendarat ke lantai dengan sikap awal, stopwatch dihentikan. Demikian juga dengan kaki kiri, tendangan dilakukan sebanyak 3 tendangan. Pelaksanaan dilakukan 3 kali dan diambil waktu yang terbaik. Untuk ketinggian target disesuaikan dengan ketinggian orang coba. Yaitu setinggi dada untuk sasaran Mawashi geri Chudan, dan setinggi kepala untuk sasaran Mawashi geri Jodan. Untuk pengukuran waktu dinyatakan dengan bentuk dua angka dibelakang koma.

Penilaian : Skor berdasarkan waktu tercepat tendangan atlet.

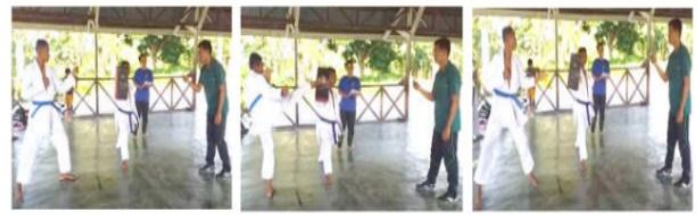

\section{Gambar 3.2 : Tahapan Pelaksanaan Tes} Sumber : Simbolon \& Siahaan, 2020

Dari data yang didapat pada penelitian, maka dapat dihasilkan norma tes kecepatan tendangan sebagai berikut:

\begin{tabular}{|c|c|c|}
\hline Waktu (Detik) Putera & Kategori & Waktu (Detik) Puteri \\
\hline$<2,12$ & Baik Sekali & $<2,60$ \\
\hline $2,56-2,13$ & Baik & $3,14-2,61$ \\
\hline $3,01-2,57$ & Cukup & $3,67-3,15$ \\
\hline $3,46-3,02$ & Kurang & $4,20-3,68$ \\
\hline$>3,47$ & Kurang Sekali & $>4,21$ \\
\hline
\end{tabular}

\section{Tabel 2.1 : Norma Tes Kecepatan Tendangan Mawashi Geri}

\section{f. Hubungan Skipping Dengan Tendangan Atas}

Latihan skipping merupakan suatu hal pembiasaan yang berulang menggunakan alat dengan seutai tali yang mudah didapatkan. Sedangkan kecepatan tendangan merupakan kualitas kondisional yang seorang olahragawan dapat melakukan gerakan sesingkat-singkatnya dengan maksimal.

Teknik skipping adalah salah satu teknik yang digunakan dalam penerapan latihan skipping pada setiap kegiatan latihannya dengan terprogram.

Teknik tendangan adalah salah satu teknik vital dimana teknik gerakan tendangan juga dapat digunakan pada saat menyerang lawan selain dengan mengandalkan penggunaan pukulan.

Berikut merupakan beberapa jenis tendangan yang perlu kalian perhatian dan bahkan dikuasai dengan baik oleh para karatedo sebagai dasar : (1) tendangan belakang, yang disebut usiro-geri, (2) tendangan menggunakan kaki bagian samping atau disnap, yang disebut yokogeri-keange, (3) tendangan menggunakan kaki bagian samping atau disodok, yang disebut yoko-geri-kekome, (4) tendangan menggunakan kaki bagian atas, yang disebut mawashi-geri, (5) tendangan yang mengarah ke bagian perut ataupun kepala 
dengan arah ke depan, yang disebut maegeri.

Untuk mendapatkan Tendangan yang baik dan kecepatan yang maksimal dibutuhkan teknik latihan yang maksimal, koordinasi dan yang paling utama adalah kekuatan otot tungkai. Untuk melatih otot tungkai tersebut dapat ditempuh melalui lompat tali atau skipping.

Latihan skipping dianggap dapat berpengaruh karena latihan ini merupakan salah satu jenis latihan yang dapat meningkatkan power tungkai. Latihan skipping adalah latihan yang dilakukan dengan cara melompat ke atas yang dilakukan berulang-ulang dengan tali sebagai medianya.

\section{METODE}

Jenis penelitian ini adalah studi literatur atau penelitian kepustakaan. Menurut Suarifqi Diantama, studi literatur dilakukan dengan cara mempelajari dan mengkaji buku- buku yang ada hubungannya dengan masalah yang diteliti untuk memperoleh bahan-bahan atau sumber informasi tentang masalah yang diteliti. Teknik ini selain digunakan untuk melengkapi serta memperkuat landasan peneliti dalam melakukan penelitian juga untuk melengkapi hasil penelitian yang peneliti lakukan. Teknik ini dilakukan dengan cara mengumpulkan berbagai macam sumber dan literatur buku-buku yang berkaitan dengan masalah yang sedang diteliti. Dengan mempelajari bukubuku yang berhubungan dengan penelitian, diharapkan peneliti dapat memperoleh data secara teoritis sebagai penunjang penelitian.

Sedangkan menurut Zed dalam kutipan jurnal Syauki dan Endrik (2020) penelitian kepustakaan adalah aktifitas yang pasif, statis, dan bias. Yakni usaha memperoleh data dengan cara mendalami, mencermati, menelaah pengetahuan yang ada didalam kepustakaan (sumber Buku, Jurnal Internasional, Skripsi terdahulu dan Jurnal Nasional).

Penelitian kepustakaan atau kajian literatur (literature riview, literature research) merupakan penelitian yang mengkaji atau meninjau secara kritis pengetahuan, gagasan, atau temuan yang terdapat di dalam tubuh literatur berorintasi akademik (academic-oriented literature) serta merumuskan kotribusi teritis dan metodologisnya untuk topik tertentu (Taylor dalam Farisi. 2010).

\section{a. Teknik Pengumpulan Data}

Teknik pengumpulan data yang digunakan dalam penelitian ini meliputi data dari literatur maupun referensi yang ada mengenai latihan skipping terhadap peningkatan kecepatan tendangan atas pada atlet karate. 
Ahmad Yanuar Syauki ${ }^{1}$, Bambang Yunanto ${ }^{2}$, dan Siti Maesaroh ${ }^{3}$. Analisis Penerapan Latihan Skipping Untuk Meningkatkan Kecepatan Tendangan Atas Pada Atlet Beladiri Karate

Teknik ini disebut juga dengan studi pustakaya yaitu cara menelusuri keputakaan yang berisi tentang teori-teori dari karya ilmiah baik yang sudah diterbitkan atau belum diterbitkan berupa hard copy atau soft copy yang ada pada makalah, jurnal online. Data yang digunakan sebagai berikut : (1) buku, (2) journal ilmiah, (3) skripsi terdahulu, (4) artikel.

\section{b. Teknik Analisis Data}

Analisis data dilakukan untuk mengolah dan menginterprestasi data dengan tujuan memperoleh informasi yang sesuai untuk tujuan penelitian. teknik analisis data adalah proses sebuah proses penyederhanaan data ke dalam bentuk yang lebih mudah dibaca dan interprestasikan. dalam menganalisis data, teknik analisis data yang digunakan dalam penelitian dengan model yang terdiri dari tiga tahap, antara lain reduksi data, penyajian data dan penarikan kesimpulan/verifikasi yang dapat di lihat melalui bagan berikut :

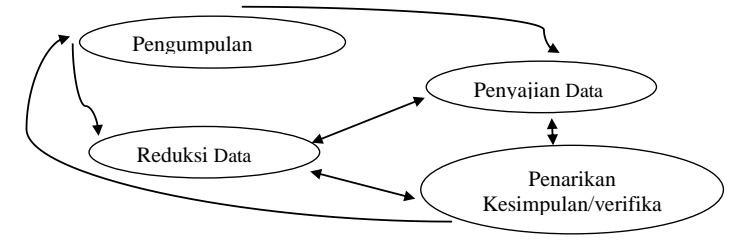

\section{Bagan 1.1: Komponen-Komponen Analisis Data}

Langkah pertama, merangkum data adalah merangkum, memilih dan memfokuskan hal-hal pokok dan hal-hal yang dianggap penting, dengan upaya mencari tema dan polanya.

Langkah kedua, peneliti menyajikan (display) data yakni menyajikan data dalam penelitian kualitatif melalui sejumlah teks yang bersifat naratif.

Langkah ketiga, peneliti menarik kesimpulan dan verifikasi sebagai jawaban terhadap rumusan masalah yang telah dituangkan sejak awal. kesimpulan merupakan kegiatan yang dilakukan dengan tujuan mencari arti, makna, penjelasan yang dilakukan terhadap data yang telah dianalisis dengan mencari halhal penting. kesimpulan ini merupakan jawaban atas permasalahan yang ingin dikaji sebagaimana dijelaskan pada identifikasi dan perumusan masalah penelitian.

\section{c. Teknik Pengujian Keabsahan Data}

Keabsahan data dilakukan untuk membuktikan apakah penelitian yang dilakukan benar-benar merupakan penelitian ilmiah sekaligus untuk menguji data yang diperoleh. Teknik pengujian keabsahan data penelitian ini menggunakan Triangulasi data.

Menurut Wiliam Wiersma dalam Sugiono (2012: 372) "triangulasi dalam pengujian kreadibilitas ini diartikan sebagai pengecekan data dari berbagai 
sumber dengan berbagai cara, dan berbagai waktu". Adapun triangulasi data sebagai berikut :

1) Triangulasi sumber untuk menguji kreadibilitas data dilakukan dengan cara mengecek data yang telah diperoleh melalui beberapa sumber.

2) Triangulasi teknik untuk menguji kreadibilitas data dengan cara mengecek data kepada sumber yang sama dengan teknik yang berbeda.

3) Waktu juga sering mempengaruhi kreadibilitas data. Data yang dikumpulkan sumber-sumber untuk memberikan data yang lebih valid sehingga lebih kredibel (Diantama, 2018).

\section{HASIL DAN PEMBAHASAN}

\section{Hasil}

Penelitian ini dilakukan untuk mengetahui analisis penerapan latihan skipping untuk meningkatkan kecepatan tendangan atas beladiri pada atlet karate.

Berdasarkan sumber-sumber relevan yang di analisis menyimpulkan bahwa penerapan latihan skipping mampu meningkatkan kecepatan tendangan. Hal ini dilihat dari hasil pengaruh yang dianalisis dari sumber-sumber yang relevan serta uji validitas.

Terjadinya peningkatan tendangan dari sumber yang dianaisis biasanya menggunakan periode waktu dalam (C) 2021, Jurnal Sportif. Pendidikan Jasmani, Kesehatan dan Rekreasi e-ISSN: 2775-9873 menyimpulkan hasil penelitian yang dilakukan dengan tingkat kepercayaan = $95 \%$ atau $(\alpha)=0,05$ Dan dalam persentase peningkatan kecepatan tendangan atlet setelah diberikan latihan skipping sebesar $5,47 \%$.

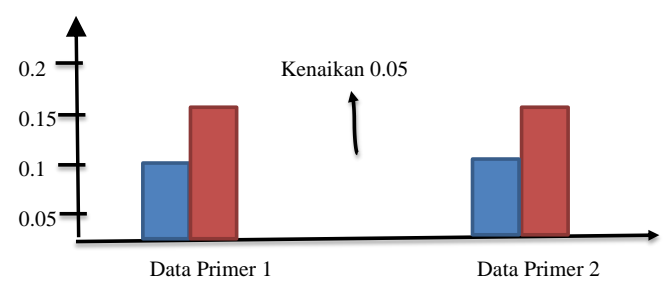

\section{Bagan 1.2 : Grafik Hasil Analisis Sumber-Sumber Data Primer}

\section{Pembahasan}

Berdasarkan analisis data yang dilakukan dalam studi literatur sebelumnya, baik dalam sumber data primer maupun sumber data sekunder dapat disimpulkan bahwa penerapan latihan skipping untuk meningkatkan kecepatan tendangan atas pada atlet beladiri karate mampu diterapkan dan dijadikan salah satu upaya dalam meningkatkan kecepatan tendangan atas pada atlet beladiri karate.

Adapun dilakukannya penelitian studi literatur menggunakan beberapa sumber seperti buku, jurnal maupun skripsi terdahulu yang berkaitan. Hal ini, sesuai dengan teknik pengujian keabsahan data. Keabsahan data dilakukan untuk membuktikan apakah penelitian yang 
Ahmad Yanuar Syauki ${ }^{1}$, Bambang Yunanto ${ }^{2}$, dan Siti Maesaroh ${ }^{3}$. Analisis Penerapan Latihan Skipping Untuk Meningkatkan Kecepatan Tendangan Atas Pada Atlet Beladiri Karate

dilakukan benar-benar merupakan penelitian ilmiah sekaligus untuk menguji data yang diperoleh. Teknik pengujian keabsahan data penelitian ini menggunakan Triangulasi data.

Dalam penelitian yang dilakukan berupa analisa sumber-sumber yang relevan dapat disimpulkan bahwa latihan skipping dapat meningkatkan kecepatan tendangan dengan menerapkan latihan skipping dalam program latihannya menggunakan periode waktu dengan tingkat kepercayaan $=95 \%$ atau $(\alpha)=$ 0,05. dan Hal ini dikarenakan latihan skipping dalam penelitian ini bertujuan untuk meningkatkan kecepatan tendangan lebih baik lagi. Dalam penerapan latihan skipping tetap mengikuti instrumen tes yang sesuai dengan teori agar tidak terjadi kelelahan otot pada penggunaannya.

Pernyataan ini, didukung oleh berbagai penelitian terdahulu yang memperoleh peningkatan kecepatan tendangan ketika menerapkan latihan skipping dalam suatu program latihan secara signifikan dan dibuktikan dengan melalui Uji Keabsahan data.

\section{PENUTUP}

\section{Simpulan}

Dari beberapa sumber yang digunakan seperti skripsi, jurnal dan buku yang termasuk data primer atau pun sekunder yang di dalamnya membahas tentang variabel $\mathrm{x}$, variabel $\mathrm{y}$ ataupun variabel $\mathrm{x}$ dan variabel $\mathrm{y}$, menambah pengetahuan kita tentang pengertian skipping, pengertian kecepatan tendangan, teknik tendangan, faktor yang mempengaruhinya serta penerapan latihan skipping untuk meningkatkan kecepatan tendangan atas, sabit atau tendangan lainnya.

Dari rumusan masalah yang diambil Dapat disimpulkan bahwa latihan skipping dapat meningkatkan kecepatan tendangan atas beladiri pada atlet karate dengan menerapkan latihan skipping dalam program latihannya, kesimpulan ini didukung dengan dua data primer yang dianalisis yaitu data primer 1 : skripsi siti cholifah dan data primer 2 : jurnal fian ferdiansyah.

Analisis sumber ini dibuktikan dengan uji keabsahan. Maka bisa disimpulkan bahwa penerapan latihan skipping secara signifikan terhadap keberhasilan mampu meningkatkan kecepatan tendangan atas beladiri pada atlet karate.

\section{Saran}

Berdasarkan kesimpulan dari hasil penelitian, maka peneliti mengajukan saran sebagai berikut :

1. Bagi atlet, latihan skipping bisa 
dijadikan sebagai referensi dalam program latihannya, untuk meningkatkan kemampuan kecepatan tendangan atas beladiri pada atlet karate dengan tetap melihat instrumen yang telah ditentukan, tidak berlebihan namun tetap konsisten.

2. Bagi STKIP Banten, menambah referensi penelitian untuk penelitian selanjutnya.

3. Bagi peneliti selanjutnya dalam melakukan penelitian mengenai latihan skipping perlu mengetahui langkahlangkah penggunaan latihan skipping dalam setiap program latihan untuk mengetahui manfaatnya.

4. Bagi pelatih, menerapkan latihan skipping dalam suatu program latihan yang digunakan para atlet dalam memaksimalkan kecepatan tendangan karena sesuai dengan hasil penelitian ini, latihan skipping mampu meningkatkan kecepatan tendangan.

5. Hendaknya proses program latihan tetap memperhatikan ukuran tes pengukuran dalam setiap atlet, karena ukuran fisik atlet putra dan atlet putri sangat berbeda.

\section{DAFTAR PUSTAKA}

Afrizal, (2018) Pengaruh Latihan Skipping Terhadap Lompat Tinggi Gaya Gunting Pada Siswa Putri Kelas V Sd Negeri 117 Palembang, Jurnal
AKRAB JUARA, Vol 3 No1 Edisi Februari (1-9).

Bagia, M. (2016). "korelsi berat badan dan panjang tungkai terhadap kecepatan tendangan karate mawashi geri jodan siswa smp negeri 11 denpasar". Jurnal Pendidikan Kesehatan Rekreasi. Volume 2 : 119 127, Agustus.

Diantama, S. (2018). Metode Penelitian Pendidikan. Bandung: Pustaka Rahmat.

Fandayani, W \& Sagitarius. (2019). Analisis Teknik Tendangan Dominan terhadap Perolehan Poin pada Pertandingan Kumite Cabang Olahraga Karate, Volume, 11. No, 1.

Fenanlampir, A \& Faruq, M (2015). Tes \& Pengukuran dalam Olahraga. Yogyakarta: CV Andi Offset.

$\checkmark$ KARATE: Pengertian, Sejarah, Aliran, Teknik, Peraturan Pertandingan (yuksinau.id)

Magfirah, N, I. (2016). Pengaruh Latihan Skipping Terhadap Kardiovaskular Endurance Pada Kelompok Cabang Olahraga Beladiri. Fakultas Kedokteran Universitas Hasanuddin Makassar.

Roni Fajar Simbolon \& David Siahaan. (2020). Pengembangan Instrumen Tes Kecepatan Tendangan Mawashi Geri Pada Cabang Olahraga Karate. Jurnal Prestasi Vol, 4 No. 2, Desember.h.52-5

Pramudani, A, H, dkk. (2018). Pengaruh Latihan Skipping Terhadap Vertical Jump Mahasiswa Fakultas Kedokteran Universitas Diponegoro, JKD, Vol 7, No 4. 
I Ahmad Yanuar Syauki ${ }^{1}$, Bambang Yunanto ${ }^{2}$, dan Siti Maesaroh ${ }^{3}$. Analisis Penerapan Latihan Skipping Untuk Meningkatkan Kecepatan Tendangan Atas Pada Atlet Beladiri Karate

Purba, P, H, Bangun, S, Y \& Siahaan, D. (2019). Upaya Meningkatkan Kecepatan Tendangan Maegeri Chudan Melalui Modifikasi Latihan Squat Jumps Dan Latihan Split Jumps Pada Atlet Karate Wadokai Dojo Sma Negeri 11 Medan. (Physical Education, Health and Recreation; Vol. 3, No.2)

Syahril, M. (2020). Buku Jago Beladiri. Pamulang - Tangerang Selatan : Cemerlang.

Syauki, A, Y \& Endrik. (2020). Latihan $\begin{array}{lcr}\text { Massed } & \text { Practice } & \text { Melalui } \\ \text { Keterampilan } & \text { Pukulan } & \text { Smash } \\ \text { Bulutangkis. } & \text { Jurnal } & \text { Sportif. }\end{array}$ Pendidikan Jasmani, Kesehatan dan Rekreasi. Volume 5, No. 2
Wardanius, K. (2021). Pelatih Beladiri Karate Dojo Kaswa. Kragilan.

Warisyanti, Y. Upaya Peningkatan Hasil Belajar Lompat Jauh Melalui Pendekatan Bermain Lompat Tali pada Siswa Kelas IV Sekolah Dasar, Jurnal Pendidikan Ilmiah Volume 5, Nomor 3. 